\title{
EXPANDED PERLITE, EXPANDED VERMICULITE AND MICROSPHERES AS FILLERS IN NEW GENERATION PAPER PULP MIXTURES USED FOR CONTACT WITH LIQUID METAL
}

\author{
Zbigniew Zawieja' ${ }^{1}$ Jacek Sawicki' \\ 1 Institute of Materials Science and Engineering, Lodz University of Technology, Stefanowskiego St. 1/15, \\ 90-924 Lodz, Poland, e-mail: 800521@edu.p.lodz.pl
}

Received: 2015.04.03

Accepted: 2015.05 .08

Published: 2015.06.01

\begin{abstract}
Liquid metal when filling sand casting mould while pouring it out from ladle at the first moment comes across the sprue/gate system of the mould the purpose of which is to transfer liquid metal and feed the mould recess. The materials presently used for the elements of the sprue/gate systems are based on ceramics or the mixtures based on paper pulp. In this study the use of alternative mineral additions such as expanded perlite, expanded vermiculite, and microspheres as the fillers to paper pulp acquired from waste-paper for the use for the elements of mould sprue/gate systems or also other applications for the contact with liquid metal are presented. Experimental mould tube shapes made on the basis of the paper pulp based mixture patented by the authors were poured over with liquid metal. For the comparison, ceramic shapes and commercially available cellulose shapes were investigated in the same way. In order to compare the crystallization processes, a measurement of the cooling off liquid metal was carried out for all the analysed tube samples. From the so obtained metal samples metallographic microsections were made to compare cast iron microstructures. The results obtained from the investigations carried out have shown that the patented paper pulp based mixture may well be applied as an alternative material used for the elements of the sprue/gate systems for disposable sand moulds.
\end{abstract}

Keywords: expanded perlite, expanded vermiculite, microspheres, paper pulp.

\section{INTRODUCTION}

The conventional technologies of casting in sand moulds are in fact unchanging for many years [1-8]. Liquid metal, when filling sand cast mould at the first moment of pouring it out from ladle comes across the sprue/gate system of the cast mould, and the purpose of this system is to transfer the liquid metal and feed the mould recess. Therefore, the sprue/gate system fulfils the key role in the entire technology of the manufacture of sand moulds, and as a consequence of the manufacture of the cast. This concerns both the geometry of the mould sprue/gate system and the materials it is made of. In many cases the mould sprue/gate system constitutes only a system of channels cut in moulding sand, but the most often it is necessary to use ready half-finished products, usually in a form of tube shapes. Such shapes are manufactured mostly from ceramic materials [9, 10]. However, the inventive solutions appeared based on other materials [11-13]. Ceramic materials, due to their characteristics may make the process of the reclamation of moulding masses difficult [5] and they generate in consecutive stages undesirable effect of the contamination of circulating moulding sand. The cellulose based materials available at present during the thermal degradation show a considerable level of the emissivity of volatile compounds $[12,16]$.

In this study the authors have presented the application of the patented mixture of paper pulp enriched with mineral admixtures such as expanded perlite, expanded vermiculite, and microspheres 
for the use for the elements of mould sprue/gate systems or other applications for the contact with liquid metal [13]. The tube shapes manufactured on the basis of the paper pulp based mixture patented by the authors were poured over with liquid metal. For the comparison ceramic shapes and commercially available cellulose shapes were investigated in the same way. In order to compare the crystallization processes a measurement of the cooling off liquid metal was carried out for all the analysed tube samples . From the so obtained metal samples metallographic microsections were made to compare cast iron microstructures.

\section{MATERIALS AND METHODOLOGY}

For the investigation cylindrical shapes of the size $\varnothing 60 \times 300 \mathrm{~mm}$ made of 4 different materials were used. The investigations were carried out for ceramic shapes, commercial cellulose based shapes, and two types of experimental shapes of patented material composition [13]. The composition of the patented mixtures is shown in Table 1. The investigated shapes were poured over with grey cast iron of EN-GJL 250 type melted in induction melting furnace of PI30 type with the capacity of $30 \mathrm{~kg}$. In the diagram (Fig. 1) the measurement-investigation stand used at the investigation is shown. The measurements of the temperatures of crystallizing metal in the shapes were carried out with the use of the thermoelements of PtRh10-Pt type which were connected with the use of compensation conductors to the Cristaldigraph, voltage-frequency converter.

From the samples obtained as the result of pouring them over with liquid cast iron metallographic microsections were carried pit in order to compare microstructures. The metallographic investigations were made on cross-microsections on the Nikon-MA200 microscope. For the etching of samples nital was used and enlargements $\times 100$ and $\times 1000$ were applied.

\section{RESULTS}

In the charts (Figs. 2-5) the results of the measurements of the temperature of the liquid metal getting cold in the analysed tube shapes are presented.

When analysing the temperature changes in time, it can be observed that for the commercial cellulose shape (Fig. 3) and the experimental shape \#1 (Fig. 4) an exothermic effect occurs maintaining the temperature of the liquid metal constant for a certain time. For the ceramic shape (Fig. 2) and the experimental one \#2 (Fig. 5) the temperature measurements carried out did not show any additional exothermic effect.

When considering the course of the crystallisation process of the eutectic it can be noted that

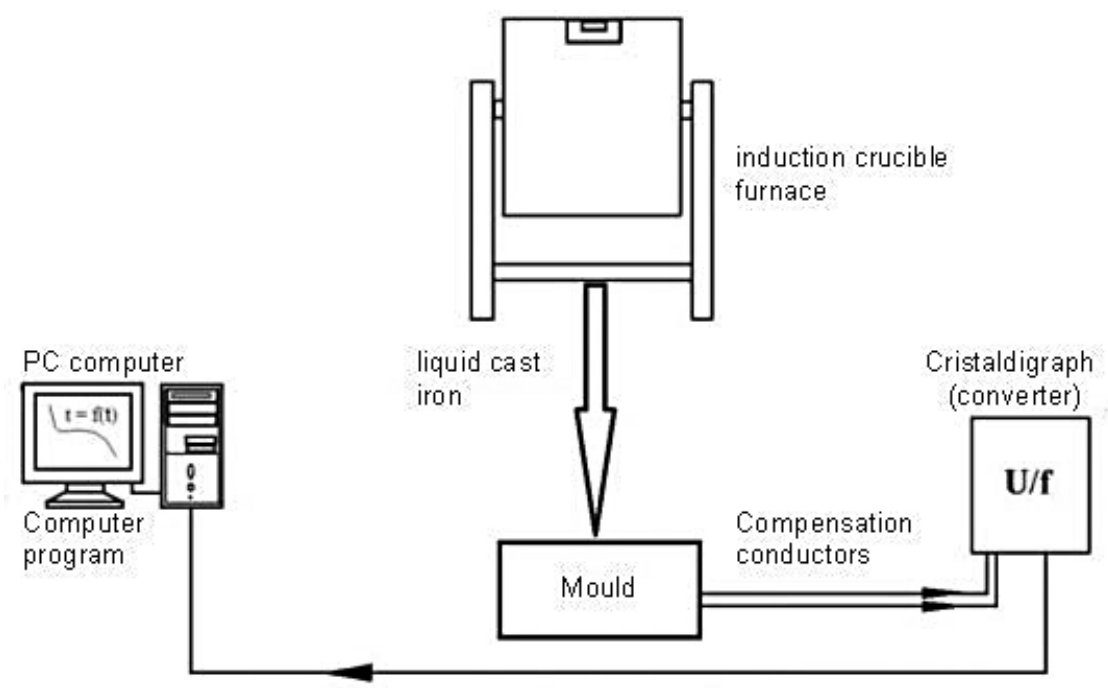

Fig. 1. Block diagram of investigation-measurement stand

Table 1. The material composition of the patented shapes used for the investigations

\begin{tabular}{|c|c|c|c|c|c|}
\hline Specification & Paper pulp [g] & Exp.perlite [g] & Exp.vermiculite [g] & Microspheres [g] & Binder [g] \\
\hline Own cellulsoe \#1 & 270 & 15 & 30 & 80 & 190 \\
\hline Own cellulsoe \#2 & 270 & 15 & 30 & 0 & 151 \\
\hline
\end{tabular}




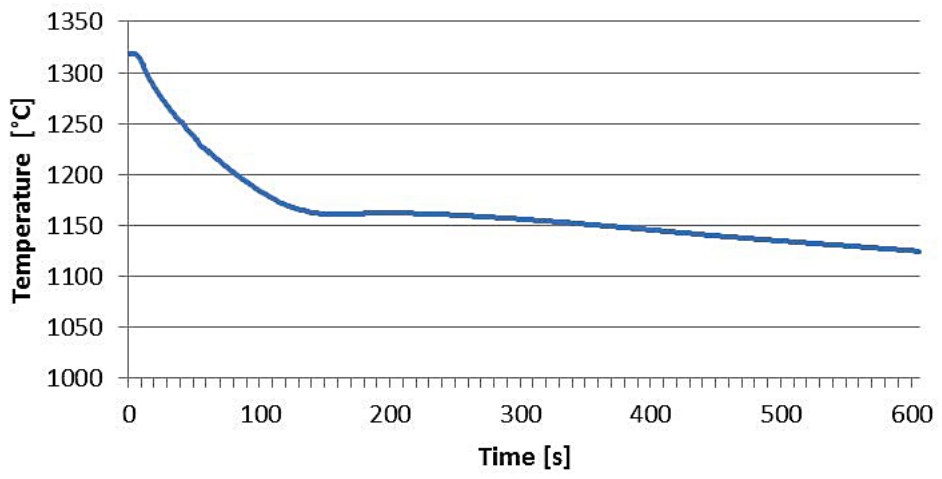

Fig. 2. The chart of the temperature change versus time during the pouring over of a ceramic shape with cast iron

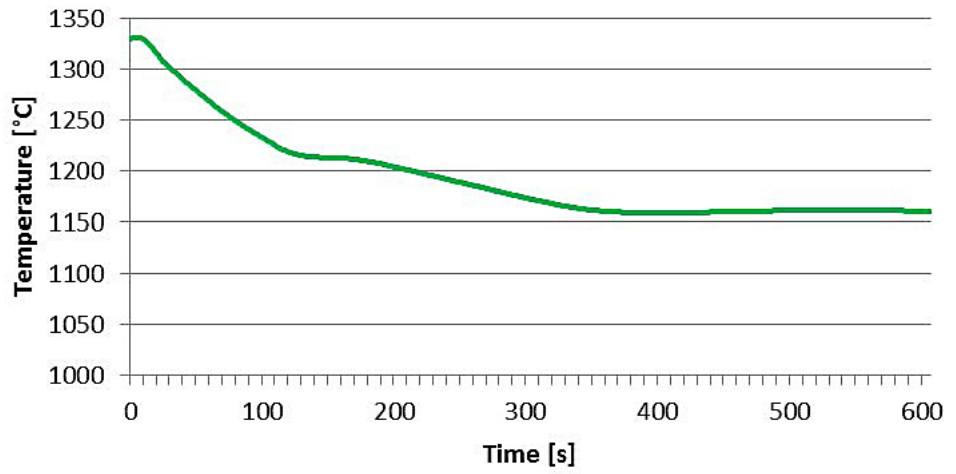

Fig. 3. The chart of the temperature change versus time during the pouring over of a commercial cellulose shape with cast iron

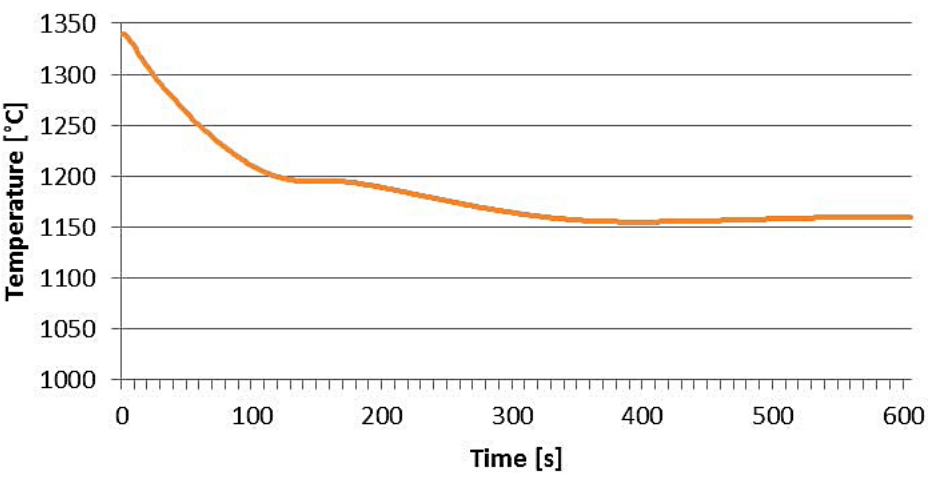

Fig. 4. The chart of the temperature change versus time during the pouring over of a experimental shape \#1 with cast iron

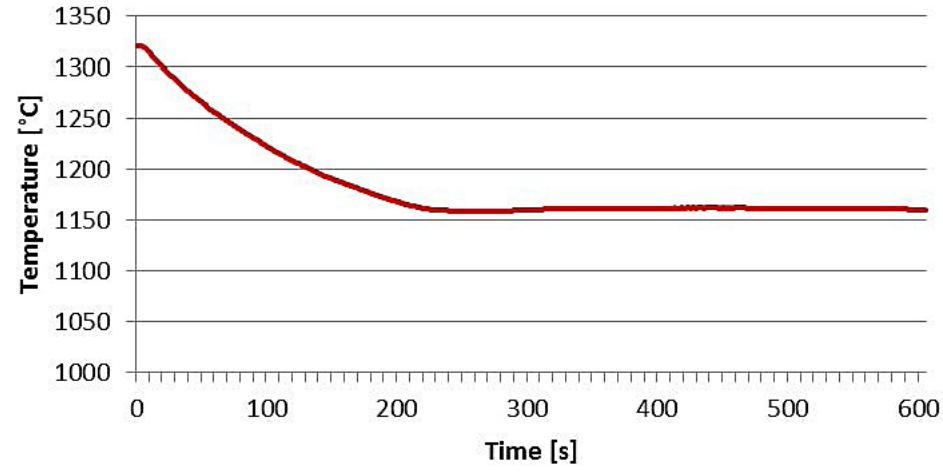

Fig. 5. The chart of the temperature change versus time during the pouring over of a commercial cellulose shape \#2 with cast iron 
it starts quickest in the ceramic shape (Fig. 2), i.e. after about 130 seconds. For the experimental shape \#2 (Fig. 5) containing no microspheres poured over with liquid cast iron the eutectics begins crystallizing after about 200 seconds. The metal remains in the liquid state for the longest time when pouring over of the commercial cellulose shape (Fig. 3) and the experimental \#1 one
(Fig. 4), and in both cases the crystallization of the eutectics begins after about 300 seconds.

The photos of the microstructures of cast iron samples obtained after the process of pouring over of the investigated samples are presented in Figures 6-9. For all the analysed samples the metal microstructures composed of flake graphite, ferrite, and perlite were obtained.

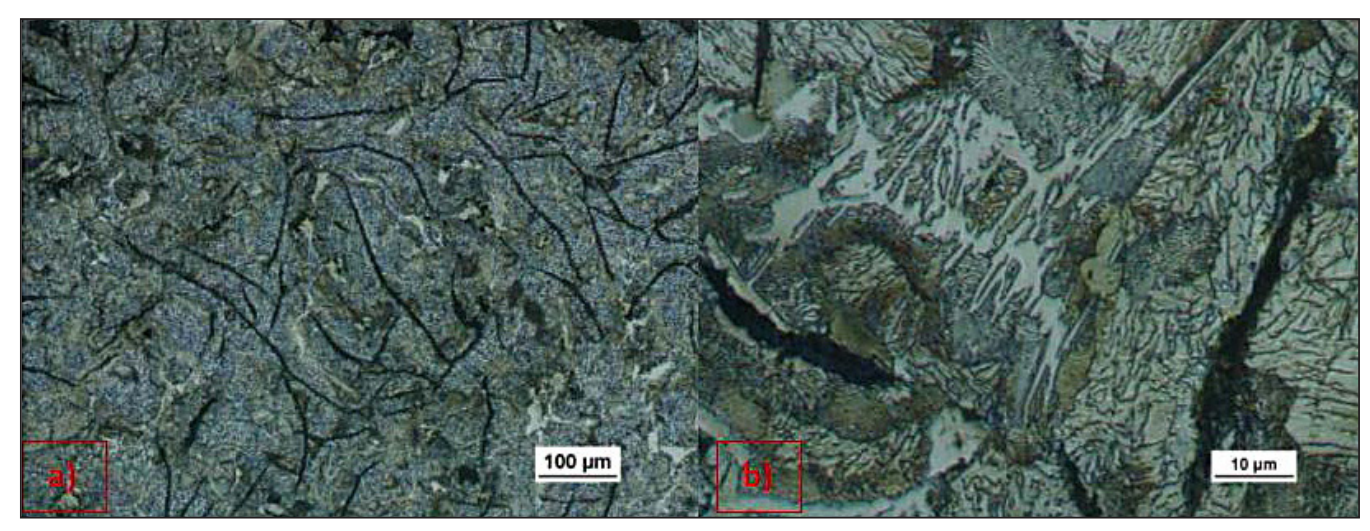

Fig. 6. The cast iron microstructures obtained with the use of ceramic shape a) enlargement $\times 100$, b) enlargement $\times 1000$

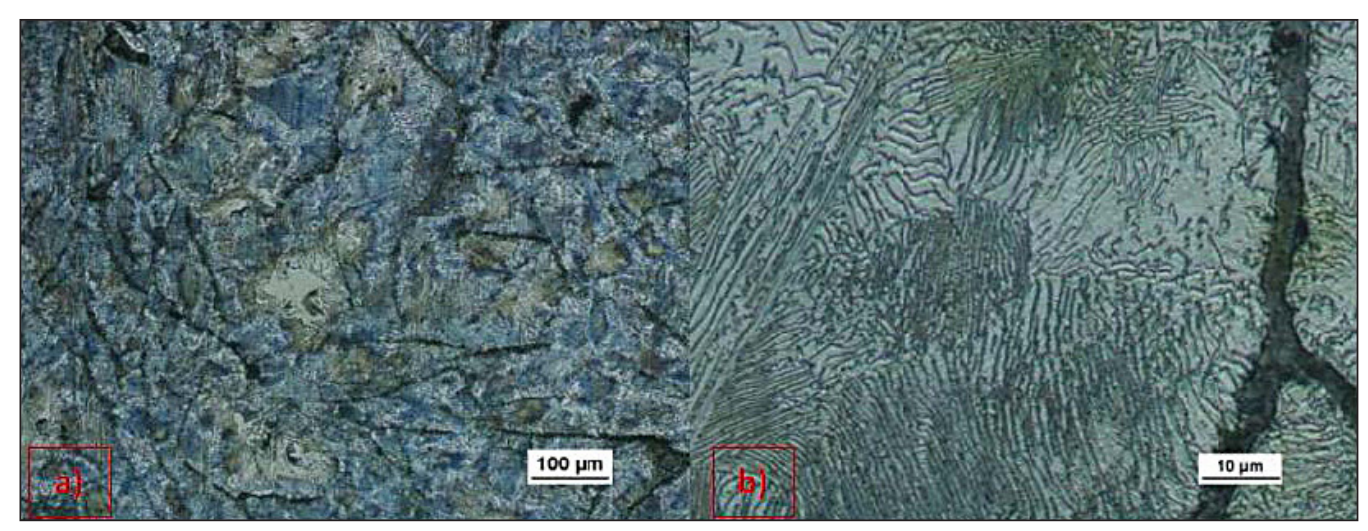

Fig. 7. The cast iron microstructures obtained with the use of commercial cellulose shape a) enlargement $\times 100$, b) enlargement $\times 1000$

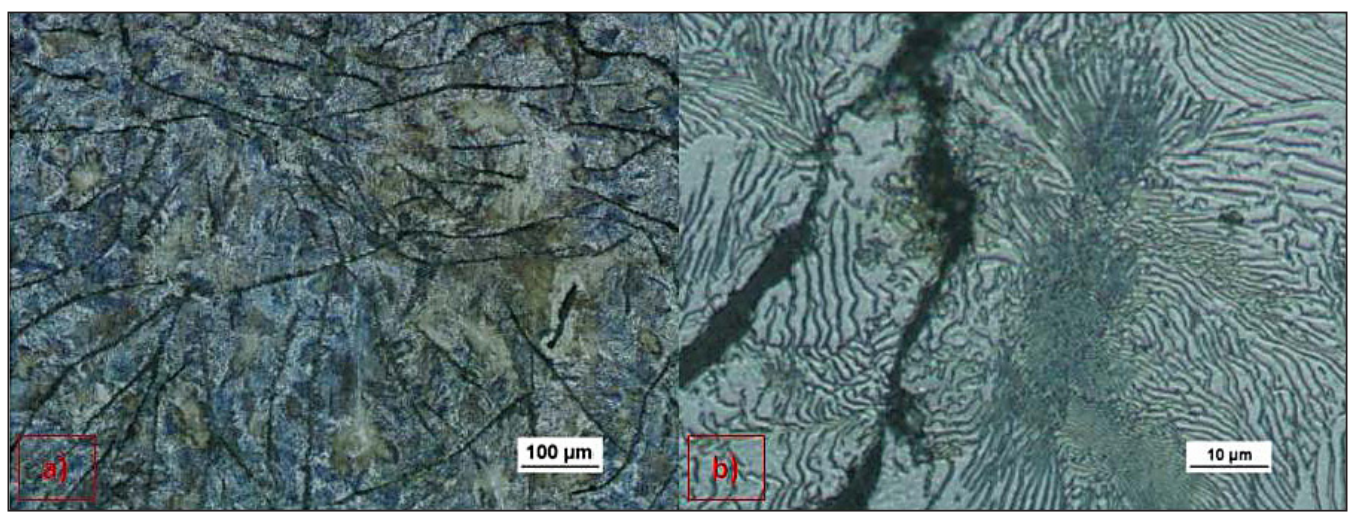

Fig. 8. The cast iron microstructures obtained with the use of experimental shape \#1 enlargement $\times 100$, b) enlargement $\times 1000$ 


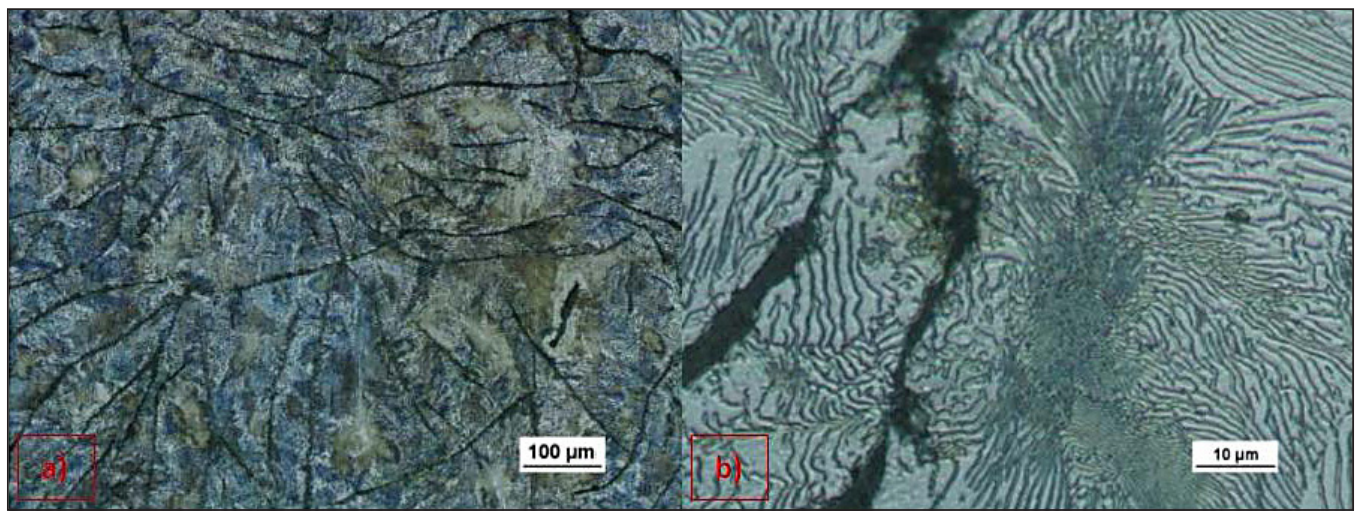

Fig. 9. The cast iron microstructures obtained with the use of experimental shape \#2

a) enlargement $\times 100$, b) enlargement $\times 1000$

\section{DISCUSSION AND CONCLUSIONS}

The presented investigation results show that it is possible to apply alternative material compositions based on the paper pulp mixture enriched with the fillers of the increased thermal resistance, as patented by the authors of this study. The current knowledge of the expanded vermiculite [17$21]$, expanded perlite [22, 23], and microspheres $[24,25]$ proves their higher thermal resistance when compared to the cellulose based unmodified materials $[11,12]$. The exothermic effect for the commercial cellulose sample and the experimental \#1 one is connected with the occurrence of microspheres which, to a certain temperature level, behave as an admixture improving the insulation ability of the mixture, whereas after exceeding the limit temperature they trigger exothermal effects $[12,15,16]$.

The process of the softening of expanded perlite starts in the temperature of the range $871-1093{ }^{\circ} \mathrm{C}$, and the range of melting temperature is $1260-1343{ }^{\circ} \mathrm{C}$. The temperature of the sintering of microspheres occurs at the level of $1000{ }^{\circ} \mathrm{C}$, and the temperature of melting is assumed for the level of $1400{ }^{\circ} \mathrm{C}$. The thermal resistance of expanded vermiculite is on the level of $1240-1430{ }^{\circ} \mathrm{C}$, and in this range of temperature a coagulation process takes place, and then melting, where the melting temperature is not defined. The range of the operation ability of the listed materials is so sufficient that, as the investigations carried out show, they can constitute a filler for the base material on the base of the cellulose obtained from waste-paper.

The use of expanded perlite, expanded vermiculite, and microspheres as the admixtures increasing the thermal resistance of cellulose mix- ture has turned to be an appropriate choice. These materials show very interesting physicochemical properties that can be used also for the contact with liquid metal in the form of the shapes for the construction of sprue/gate systems of disposable sand moulds. The use of the aluminosilicate binders did not cause any considerable deviations at the course of the temperature change during measurements. It allows for the use of this resin for the applications of this type which is insofar essential that it is a more friendly material for human health and life than the materials used for the cellulose commercial shapes $[12,15,16,26]$.

No additional non-metallic inclusions or other contaminants which might originate from the fillers used in the patented mixture of the fillers in a form of expanded perlite, expanded vermiculite, and microspheres were found.

The use of microspheres extend the time of the existence of the metal in liquid state when compared to the shapes without microspheres in their composition. Therefore, this justifies the use of this filler since the maintaining of metal in liquid state in the cast system for longer time than in the mould reproducing the cast allows to avoid casting defects in the transition zone resulting from the natural process of metal shrinkage in the course of its crystallization.

\section{REFERENCES}

1. Sakwa W. (ed.): Poradnik Inżyniera Odlewnictwo. WNT Warszawa, 1986.

2. Kosowski A.: Zarys odlewnictwa. Wyd. AGH Kraków, 1997.

3. Rączka J., Haduch Z., Tabor A.: Odlewnictwo. Skrypt Politechniki Krakowskiej. Kraków, 1997. 
4. Kosowski A.: Zarys odlewnictwa i wytapianie stopów. Wyd. AGH, Kraków 2001.

5. Holtzer M.: Gospodarka odpadami i produktami ubocznymi w odlewniach. Wyd. AGH, Kraków 2001.

6. Szweycer M., Nagolska D.: Metalurgia i odlewnictwo. Wyd. Politechniki Poznańskiej, Poznań 2002.

7. Perzyk M.: Odlewnictwo. WNT, Warszawa 2009.

8. Granat K., Chorzępa S.: Odlewnictwo. Oficyna Wydawnicza Politechniki Wrocławskiej. Wrocław 2007.

9. http://www.awotex.eu/asortyment/link_level_2_7/ ksztaltki_szamotowe trisam - katalog firmy, z dnia 06-04-20-14.

10. http://www.refrasil.cz/vyrobky/samotove-tvarnice/ - katalog firmy z dnia 06-04-2014.

11. http://www.foseco.com - katalog firmy z dnia 0604-2014.

12. Grabowska R., Szucki M., Suchy J., Eichholz S., Hodor K.: Degradacja termiczna materiału na bazie celulozy stosowanego do budowy układów wlewowych do odlewów żeliwnych. Polimery 1, 58, 2013, 39-44.

13. Zawieja Z., Sawicki J.: Zgłoszenie patentowe z dnia 07.07.2014 r. nr P. 408770: „Mieszanka celulozowa do produkcji kształtek rurowych oraz złączek o przekroju kołowym stosowanym w układach wlewowych w odlewnictwie."

14. Pysz S., Stachanczyk J.: Filtracja staliwa - symulacja procesu na przykładzie odlewu o masie $70 \mathrm{~kg}$. Archiwum Odlewnictwa, rocznik 6, 18(1/2). 2006, 413-418.

15. Zawieja Z., Sawicki J., Gumienny G, SobczykGuzenda A.: Investigation of an advanced cellulose profile used for the manufacture of gating systems. Archives of Foundry Enginnering, 13(3), 2014, 123-128.

16. Zawieja Z., Sawicki J., Gumienny G.: Analiza porównawcza kształtek ceramicznych $\mathrm{z}$ celu- lozowymi wykorzystywanymi do tworzenia układów wlewowych w odlewnictwie. Inżynieria Materiałowa 5, 2014, 434-437.

17. Suvorov S.A., Skurikhin V.V.: Vermiculite - a promising material for high-temperature heat insulators. Novyer Ogneupory, 2, 2003, 44-52.

18. Suvorov S.A., Skurikhin V.V.: High-Temperature heat-insulating materials based on vermiculite. Novyer Ogneupory, 12, 2002, 24-31.

19. Peletskii V.E., Shur B.A.: Experimental study of the thermal conductivity of heat insulation materials based on expanded vermiculite. Novye Ogneupory, 11, 2007, 41-43.

20. Liang Y., Yu J., Feng Z., Ai P.: Flammability and thermal properties of bitumen with aluminium trihydroxide and expanded vermiculite. Construction and Building Materials 48, 2013, 1114-1119.

21. Kristkova M., Weiss Z., Filip P.: Hydration properties of vermiculite in phenolic resin friction composites. Applied Clay Science, 25(3-4), 2004, 229-236.

22. Pichor W., Janiec A.: Thermal stability of expanded perlite modified by mullite. Ceramics International 1, 2009, 527-530.

23. Demirborga R., Gul R.: Thermal conductivity and compressive strength of expanded perlite aggregate concrete with mineral admixtures. Energy and Buildings, 35(11), 2009, 1155-1159.

24. Losiewicz M., Halsey D., Dews J., Olomaiye P., Harris F.: An investigation into the properties of micro-sphere insulating concrete. Construction and Building Materials, 10(8), 1996, 583-588.

25. Mazzoni A.D., Aglietti E.F.: Aluminium reduction and nitriding of aluminosilicates. Thermochimica Acta, 327(1), 1999, 117-123.

26. Posniak M., Koziel E., Jeżewska A.: Szkodliwe substancje chemiczne w procesie przetwórstwa żywic fenolowo-formaldehydowych. Bezpieczeństwo Pracy Nauka i Praktyka, 3, 2000, 8-11. 